\title{
Pendulum: After Endsars Saga What Next?
}

\author{
Iyanuoluwa Ezekiel Bamidele
}

\begin{abstract}
This article argues that the \#endsars movement and subsequent turn of events is largely as a result of unfavorable governmental political system and policies as well as lack of true federalism which has existed for decades. The article submits that the \#endsars movement merely addresses a hole in the system which within a short time exposed the decay and rot and incapability of the system to get the nation to a safe haven. If the system is good then neither sars nor any other security would have acted out of place.
\end{abstract}

Keywords: Pendulum, States

DOI: $10.7176 / \mathrm{IAGS} / 90-01$

Publication date: February $28^{\text {th }} 2021$

\section{Introduction}

Merriam-Webster's dictionary defines a pendulum as a state of affairs that alternates between opposites. The \#endsars movement is one that alternates between the government of Nigeria and the Nigerian youths, owing to series of police brutality by the special anti-robbery squad commonly known as 'SARS'

The movement which started online later snowballed into a nation-wide peaceful protest. However, subsequent actions from both the government and the youths of the Nigerian populace showcased lots of decay not only in the Nigerian policing system but the entire structure of the Nation.

Just as in the case of a pendulum which swings to and fro, it would be imperative therefore to conduct an extensive historical analysis in order to be able to locate where things went wrong and decide the best possible way to get the nation right back on track. This is premised on the view that if indeed Nigeria as a young nation once competed with other $2^{\text {nd }}$ world nations such as India, Singapore, South Africa, etc then one can say Nigeria was once on the right track. Where did the giant of Africa missed it would then be a reasonable question to ask.

Also, former president of the United States, Barak Obama was once asked what his greatest mistake as president was, he responded by saying his greatest mistake as president was not having a post-Gaddafi plan. This simply points out to the necessity of having a post \#endsars protest so that the lives and property lost would not go in vain.

\section{A little spark}

At a time like this, we must recognize that our right to rebel (protest, revolt, civil disobedience etc) is not just to destroy the order of power system in present day Nigeria but that overhauling it is a collective duty in order to arrive at the Nigeria of our dreams and aspirations.

Howard Evans Kiefer opines, "It seems to me that the duty to rebel is much more understandable than that right to rebel, because the right to rebellion ruins the order of power, whereas the duty to rebel goes beyond and breaks it (Kiefer, 1970). The indiscriminate and excessive use of force by the various institutions and commissions of the government of Nigeria without appropriate and timely reprimand by the government of the day as one would have expected in a democratic nation-state, is such that necessitated and gave birth to protests by youths and concerned citizens across various states in present day Nigeria.

The protest, one would have expected to start and end as a move against police brutality and excesses as well as extra judicial killings and abuse of human rights has however reveal in a much more clearer manner the obvious inadequacies inherent in the system and practice of government in Nigeria.

By now, under a true democratic setting the government would have taken more practical steps to address the issue - Issues I would suggest to be addressed by making sure all top police officers and personnel of the commission to have been placed on forceful retirement so the state panels that are being set up by various State government could carry out their functions within a set time frame, so accused officials and personnel would get justice served as soon as possible and an end would come to all the protest. Going forward, an extensive look at the current Inspector General of Police (IGP) Muhammed Adamu reveals that he's a top-notch police officer whose response to the call of the youths in Nigeria to put an end to the now dissolved federal Special antiRobbery Squad (SARS) as well as obliging other calls for reforms within the police and the establishment of special weapons and tactics which has received heavy criticism for its speedy formation without proper framework and equipment to carry out its operations and meet up to international Special Weapons and Tactics (SWAT) law enforcement unit's standard. But then, a careful look at things would reveal that even the IGP, Adamu, is not entirely in charge of the police force as elements in the Nigerian police force are yet to follow suit with the directory from the IGP's office to restrain from hindering protesters from exercising their rights to a peaceful protest and moreover on various news channels across the country reports were made of a police officer 
beating up peaceful demonstrators and even some quite a number of lives were lost. The lesson to be taken is that the police formation itself is too wide and complex for the IGP to give an order at the command headquarters in Abuja and expect a police officer miles away without access to information technology, light, and other basic social amenities and low income complies, as most of them are basically surviving on extortion and other illegal activities which are against the oaths which they took before assuming the duties of a police officer.

\section{The dilemma}

From the above therefore, the lesson that can be deduced is simple, if the police force can appear to be too big for the IGP then Nigeria is too big for the excessive centralization of power in the hands of the president at the federal arm of government. Scholars in Nigeria have over the years submitted that there's a need for a more holistic governmental arrangement that will encompass the true principles and doctrines of the concept of federalism and federation. Both terms can be seen as more of an ideological and philosophical concepts which will put federalism as 'value concept' that imbues federalism (Burgess, 1993: 3). While we all know federalism to be a principle 'involving the constitutional diffusion of power between the central and the constituent governments to achieve self-rule and shared rule' (Elazar, 1987: 5-6). The call for true federalism in Nigeria has over the years been a result of the workings of federalism in a country that was previously a unitary state as of 1954, which the founding fathers in a bid to formulate a more comprehensive system that will accommodate the diversity in Nigeria, threw away. However, as time progresses the effects of civil war (1967-1970) and series of coup d'état's altered the main reasons why the founding fathers had adopted federalism in place of unitary system. The numerous coups altered true federalism by accruing more power to the central government especially in issues of economy in a bid to ensure adequate control of the States by various divisions of the Nigerian military establishment. All these gave birth to nothing but a political and socio economic marginalization of varied meaning and interpretations by the major ethnic groups. The Igbo's interprets it to mean more control of their own oil rich region and participation in politics and holding of key important offices; while the Yoruba's interprets it to mean allocation of more powers to the State; and the Hausa/Fulani's seems to be the one enjoying the benefits of an altered federalism.

However, it doesn't matter the level where one ethnic group seems to find itself on the ladder, truth is the resources are not adequately shared: The North remains the epicenter of Poverty despite much hold on power by northerners and seemingly beneficial system of the country to the north in terms of quota system and federal character principle; The South-south (Niger Delta) still swims in a land polluted by crude oil; And the South-east remains home to neglected and uncompleted capital projects that could have boosted the overall economy of the federation

\section{The problem}

Besides, it was after the civil way that some Nigerians decided to kick against a weak central government which to them had encouraged secessionist move from sub national groups, which in the words of a former military head of State in Nigeria was because "Under the old Constitution, the regions were so large and powerful as to consider themselves self-sufficient and almost entirely independent; the federal government which ought to give lead to the whole country was relegated to the background" (Gowon, 1968).

By and large, one of the major background argument of this article is that the problem of Nigeria as at today stems from not returning the country to the way it was right after the civil wars and that the decision to not return it was heavily informed by a section and not the entire federation, which in a way, negates some of the basic principles of federalism. This then gave room for all successive constitutions drafted after the civil war to give more and more power to the central government, which invariably leads the Country astray from the true meaning of federalism.

Also, a thorough reconsideration of the items contained in the legislative list as divided between the exclusive and concurrent list, so as to allow a safe return to the true definition of federalism. The $1995 \mathrm{draft}$ constitution gave room for a state legislative list which the 1999 constitution did not. Besides, the 1999 constitution gave the central government way too much power, so much that in my humble opinion I consider the State governments to have been placed at a position whereby they'll remain lame without the central government thereby weakening developmental prospect across the country, as State can do barely little. This is my opinion after considering the items under the exclusive list which has a total of sixty eight items and concurrent list having only twelve.

The way out

Without further ado, socio economic imbalance resulting from the distribution of wealth cutting across sectors has eaten deeper so much that the pains it causes can no longer be tolerated by all. Another, would be the issue of representation where some parts of the Country has been seemingly barred from contesting for some key 
political position and even from getting political appointments as well as reaching a specific height in civil service sector.

What should be done?

Confucius once said 'study the past if you would define the future', which brings me to the popular phrase by General Yakubu Gowon who assumed power shortly after independence, when Nigeria still practices true federalism, he said and I quote "Money is not Nigeria's problem, but how to spend it" That statement alone suggested that Nigeria was in a good shape and form and that Nigeria was at that point in time doing well far above most second and third world countries of today e.g Singapore, South Africa, India and co. Therefore, the solution would be going back to the days where Nigeria operated a system and practices a form government that works the military junta took over.

\section{Conclusion}

In this article, I have been able to clearfully analyze without any value attachments the current state of the Nation and an extensive background of the issues that has been pointed out by peaceful demonstrators across the country were extensively explained.

Worthy of note, are the stages that normally follow suit after a protest, which is detailed below:

\section{PROTEST - INSURRECTION - REVOLUTION}

This is to say that, the protest that started as a demonstration against police brutality and a move against bad governance can only be tackled if only the issues bordering around federalism are adequately and effectively addressed as a matter of national urgency.

However, if care is not taken, the protest will lead to an insurrection where many youths and forward thinking Nigerians will completely and absolutely go beyond the control of any government which will invariably lead to a revolution, bringing about an absolute change to the Niger-area of West Africa (NIGERIA). This certainly, is what is going on the country as there is now a massive breakdown of law and order and the Hobbesian state of nature is gradually setting in, looters and hoodlums looting government and private owned business as well as properties. I, therefore would suggest the following as immediate steps the government can take in order to permanently address the issues at hand:

- Reduction of the powers of the central government: 'as a way out of the over-centralization of the system, the country's fiscal federalism should emphasize revenue generation rather than revenue distribution, as this would ensure fiscal viability of the states' (Babalola, D. 2017).

- Revenue sharing: an extensive review of the quota system in order to birth a system which shall be a giant step towards achieving a true federalism.

- Equal representation: more than enough has been allocated to the Federal government alone which need to be reviewed so as to redirect excessive pay and allowance of the representative democracy been practiced. However, representation in present day Nigeria favors a part than the others, for peace to reign I'd suggest representation be equally allocated to each region.

- Federal character principle: much has been said on the issue of federal character and they all point to the simple truth that true federalism in Nigeria would start with her federal character principle, in order to accommodate all disparities.

semi presidential federal representative Democratic republic - to allow further power diffusion at the central government while creating more opportunities for collective representation of different views from two distinct ethnic groups per four year tenure.

\section{Submissions}

$>$ Semi presidential federal representative Democratic republic - to allow further power diffusion at the central government while creating more opportunities for collective representation of different views from two distinct ethnic groups per four year tenure. That is a president existing alongside a prime minister with both coming from two different ethnic backgrounds.

$>$ Electoral college - to be modeled in such a way that the votes of the college can only be counted as been superior to the votes of the electorates (irrespective of the polls) when the electorates votes refuses to produce an elected representative from a different geo-political zone. This will thereby ensure all six geo-political zones are represented from time to time in a rotational manner. Thus bringing federalism to actual practice rather than the pages of paper

$>$ Change of official name - to be changed to the 'peoples federated states of Nigeria. Signaling a more independent unit of States rather than states that are heavily dependent on the central government

$>$ Legislative list - the sixty eight items under the exclusive list should be thoroughly reviewed so much that at least half of the items will be added to the mere twelve items presently listed under the concurrent list. this will actualize a true independent states. 


\section{References}

Milton K, M. Howard E, K. (1970). Ethics and Social Justice. ISBN 9780873950541.

Burgess, Michael (1993). "Federalism and Federation: A Reappraisal" in Burgess, M and Gagnon, Alain-G (eds.), Comparative Federalism and Federation: Competing Traditions and Future Directions, New York; London: Harvester Wheatcheaf.

Elazar, Daniel, (1987). Exploring federalism. Alabama: The University of Alabama Press.

Yakubu, Gowon, (1968). Federal Republic of Nigeria, Faith in Unity (Lagos: Federal Ministry of Information, 1970), p. 108.\}

Babalola, D. (2017). 'Nigeria: A Federation in Search of Federalism'. 50 Shades of Federalism. 